\title{
Arquivos de Neuro-Psiquiatria
}

\section{Presentation}

Adherbal Tolosa*

Paulino Longo**

${ }^{*}$ Chair of Neurology of the School of Medicine of the University of São Paulo.

${ }^{*}$ Chair of Neurology of the Paulista School of Medicine.

"Arquivos de Neuro-Psiquiatria" has come into being under the guidance of Dr. Oswaldo Lange, whose efforts and perseverance have been instrumental in surmounting the countless initial obstacles that cause difficulties in achieving an objective of this nature [...]

Delay in publishing studies, or their publication in specialist journals, unquestionably represents a serious inconvenience [...] In our capacity of holding direct responsibility for the study centers that have resulted from the seedlings planted by Enjolras Vampré, we decided to combine our efforts and those of our assistants in order to add prestige in all senses to this new publication [...] It therefore gives us great satisfaction to see the first issue appearing, considering that we welcomed and encouraged the original idea from the time of its earliest stages [...].

With such great and determined support, [...], "Arquivos de Neuro-Psiquiatria" will certainly succeed in making its mark alongside similar journals within this specialty.

São Paulo, Júne 1943.

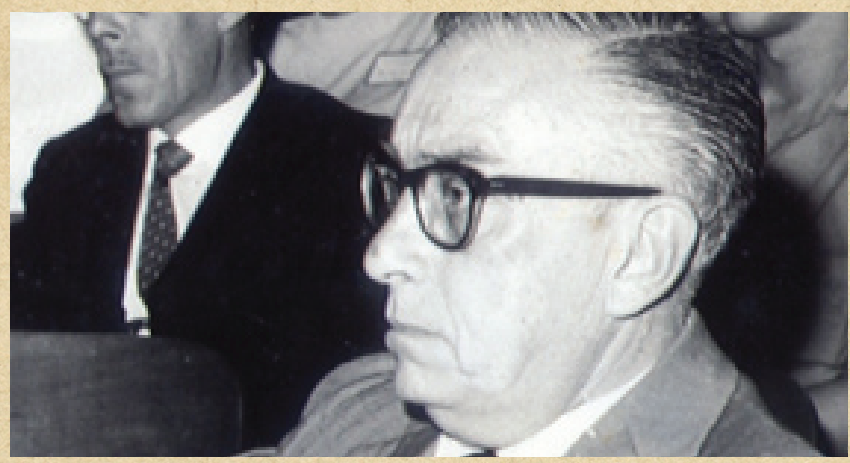

Dr. Oswaldo Lange

\section{Apresentação}

\author{
Adherbal Tolosa*
}

Paulino Longo**

*Catedrático de Neurologia da Faculdade de Medicina da Universidade de S.

Paulo.

**Catedrático de Neurologia da Escola Paulista de Medicina.

"Arquivos de Neuro-Psiquiatria" surgem sob a direção do Dr. Oswaldo Lange, a cujos esforços e perseverança se deve a transposição dos inumeráveis obstáculos iniciais que dificultam uma realização desta natureza [...]

O retardo na publicação de estudos ou sua publicação em revistas especializadas representa inquestionavelmente grave inconveniente [...] Na qualidade de responsáveis diretos pelos centros de estudos resultantes da árvore plantada por Enjolras Vampré, determinamos unir nossos esforços e os de nossos assistentes para prestigiar em todos os sentidos a nova publicação [...] Com o aparecimento do primeiro número é grande portanto a nossa satisfação, visto como acolhemos e animamos a ideia original desde suas primeiras fases [...].

Contando com tão grande e decidido apoio, [...], "Arquivos de Neuro-Psiquiatria" certamente lograrão impor-se, colocando-se ao lado de suas congêneres da especialidade.

S. Paulo, Junho de 1943.

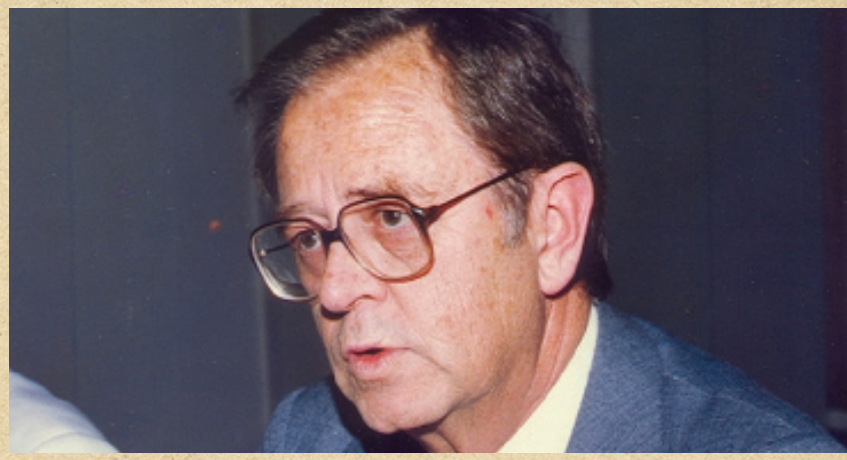

Dr. Spina França

\section{ARQUIVOS DE NEURO-PSIQUIATRIA, JUNE 2012}

Its mission is to provide neurologists and specialists in related fields with open access to original articles, editorials, review articled, images in neurology and case reports of clinical interest.

Its purpose is to contribute towards improving attendance for patients with neurological diseases, training for neurologists, clinical research, continuing education and practice guidance for neurologists.

Its vision is to be the best neurosciences journal in Latin America within the peer review system.

"We hope to go on and get better and better.

Congratulations!

The Editors" 